\title{
How Talent Management (Potential and Competencies Test) Result Influences Performance Appraisal in 2019 For Administrator / Manager Position (Echelon III) Government Employee, West Nusa Tenggara Province.
}

\author{
L R Payanta ${ }^{1} \cdot{ }^{3}$, L P Karjaya ${ }^{2}$, M Miller ${ }^{3}$ \\ 1. Regional Personnel Agency, West Nusa Tenggara Province, Mataram 83123, Indonesia. \\ 2. International Relationship Departement, Mataram University, Mataram 83123, Indonesia. \\ 3. Master in Management Courses, Vistula University, Warsaw 02-787, Poland
}

\section{Lalu Rivaliqal Payanta, MA}

Warszawa, Poland

titinmustarip@gmail.com

Lalu Puttrawandi Karjaya, MA

Mataram, Indonesia

daa_dii_doo@yahoo.com

\author{
Dr. Inz Malgorzata Miller \\ Lodz, Poland \\ gosia.miller@gmail.com
}

\begin{abstract}
This study aims to be able to see how the potential and competency assessment services affect the evaluation of ASN performance as a basis for objective and accurate selection, rotation and promotion for prospective administrator officials. In this study is quantitative with a descriptive analysis including data got from the field or sampling population to be analysed and presented a statistical interpretation in accordance with the method chosen. The conceptual framework of this research consists of independent variables, particularly: The first potential (intellectual potential, work attitude potential, personality potential, and leadership potential). The second competency (personal competence, work competence, interpersonal competence and managerial competence). For a dependent variable is an evaluation of the performance appraisal of echelon III officials (administrators) of West Nusa Tenggara province. In this study, several data sources are used as a strategy to increase the credibility of the data used. In this study, the type and source of data used are secondary data obtained by researchers indirectly through documents, potential result, competency results and performance appraisal of administrator officials data. This research will be conducted in the government of West Nusa Tenggara Province within a duration of 1 (one) year from January 2019 to December 2019, The sample size in this study was 60 people. Data analysis in this study (Univariate, Bivariate and Multivariate analysis) uses computerized data processing for the Statistical Package for the Social Sciences (SPSS) program. All hypothesis Proven There were influences among those variables Independent and Dependent. The result shows a positive relationship between potential and performance Appraisal has a modest number $(0,370)$, Value determination $(0.137)$ and with sig. (0.004). The second positive Relationship between competencies and performance appraisal shows strong influences $(0.530)$, value determination (0.263) and sig. (0.000). The last positive relationship shows from both of Independent Variable to dependent variable, Potential and Competencies Result have Simultaneously influenced the Performance Appraisal to have a strong relationship (0.640), value determination (0.410) with sig. (0.000).
\end{abstract}




\section{Kresna Social Science and Humanities Research}

Proceedings of the International Conference On Ummah:

Digital Innovation, Humanities And Economy (ICU: DIHEc) 2020 https:/doi.org/10.30874/ksshr.6

\section{Introduction}

One of the management of human resources (HR) in organizations that can improve organizational performance is performance management. Performance management according to Armstrong [1], is a systematic process to improve organizational performance by developing individual and team performance. Performance management is an ongoing process between managers and subordinates to discuss and determine how they can work together to achieve the desired results[1].

Performance management, is also an approach and development of human resources in an effort to improve career paths in the long run and for organizational development. One form of performance management is a performance appraisal which is a system used by management to evaluate individual performance in a certain period, provide feedback and foster individuals so that each individual is expected to improve their performance. Improved individual performance will certainly improve organizational performance.

To support a progressive, responsive, and participatory bureaucracy through its public service, government and development tasks, each State Civil Apparatus (ASN) is required to be professional in its field and able to guarantee the accountability of its position, in accordance with the level of each position he entrusted. Public demands on service responsiveness carried out by Civil Servants are very high at this time, therefore with the presence of the Potential and Competency Assessment Service Unit (UPPK) under the NTB Provincial Regional Personnel Agency is very helpful to bridge the gap between public demands and their competencies civil servants, by increasing the competency capabilities of civil servants through potential and competency assessments.

The low performance of the bureaucracy (PNS) results in the low quality of public services, even resulting in service users having to pay high costs (high cost economy). To realize professional and competent apparatus HR (PNS) with PNS career guidance carried out on the basis of a combination of work and career achievement systems, competency-based HR Development is a must so that the organization (bureaucracy) can realize better performance and provide services the best public. Bureaucracy must implement good and clean governance.

This study aims to be able to see how the potential and competency assessment services affect the evaluation of ASN performance as a basis for objective and accurate selection, rotation and promotion for prospective administrator officials, prospective supervisory officials and JPT Primary Open selection so that they are able to provide appropriate recommendations in the provision and placement of HR within the scope of the West Nusa Tenggara Provincial Government. 


\section{Kresna Social Science and Humanities Research}

Proceedings of the International Conference On Ummah:

Digital Innovation, Humanities And Economy (ICU: DIHEc) 2020

https:/doi.org/10.30874/ksshr.6

Nowadays, Performance is a brainwashing that must be recognized and accepted to various parties to figure out the level of achievement of an agency's appears correlated with the vision driven by an organization or company and to identify the positive and negative jolts of a viable approach. Timpe [2] (1993) expressed his point of view that people who have high performance have several peculiarities, encompassing: (a) achievement-oriented, (b) carrying determination, (c) self-control, and (d) competence.

Performance appraisal proposes to evaluate how successfully employees have hauled out their task and what they must work out to be better. This is accomplished by pointing out to the subject matter of the work they perform and what they require to obtain in every situation of their performance [3] .

McClelland's job was to be largely influential. Of specific influence was the idea that the elements or inputs correlated with individual achievement could be identified, and later explained to others. McClelland and Boyatzis [4] established a method for identifying competencies based on observing behaviours of recognized primary performers within particular organizations. Later than, different researchers measured competence and performance separately using the "behavioural event interviews" method, "behavioural observation" method and "360-degree ratings" method [5].

Over the last 30 years, several experimental researches have appeared the effectiveness and validity of the behavioural approach in competency design, which encompasses: (i) The recognition of criteria describing effective performance; (ii) the description of a precedent sample group of superior performers and a comparison group of average employees; (iii) Data collection through behavioural event interviews; (iv) the identification of competencies that distinguish superior from average performers; (v) the validation of the competency model; and (vi) the application of the design to an area of HRM functions [6].

Competency advocates support the practice of competence models for a range of purposes, consisting of selection, performance management, compensation, career management and succession planning [6, 7]. With performance management, the use of competency assessments shows to be objectively widespread [6-8]. Experimental demonstrate, however, about the effectiveness of competence designs, presuming that it can be expanded and, that there is a link between its development and performance is nevertheless unproven $[9,10]$. However, competencies are connected to job performance for individuals, but need to explore more about that [10].

Two empirical studies that followed this approach are worth mentioning. One of these studies was published in 2000 by [11], and aimed at defining a comprehensive model of competencies that are required for the job role of general practitioner (GP). To achieve such an aim, three independent studies 


\section{Kresna Social Science and Humanities Research}

Proceedings of the International Conference On Ummah:

Digital Innovation, Humanities And Economy (ICU: DIHEc) 2020

https:/doi.org/10.30874/ksshr.6

were conducted, these are: (1) behavioural events focus groups with GPs $(\mathrm{N}=35)$, (2) behavioural coding of GP-patient consultations ( $\mathrm{N}=33$ consultations), and (3) behavioural event interviews with patients $(\mathrm{N}=21)$. The data collected from the three studies provided strong evidence for a competency model comprising 11 competencies, with a summary of the associated behavioural descriptions. Example competencies included empathy and sensitivity, communication skills, clinical knowledge and expertise, conceptual thinking, and coping with pressure. The competencies derived from this study imply that a greater account of personal attributes needs to be considered in recruitment and training, rather than focusing on academic and clinical competency alone.

Throughout the years competency models have turned out to be a significant mechanism in many organizational functions, such as personnel selection, sequence planning, and performance appraisal [12]. The fundamental reasons of the fame of competency models encompass: 1) they can contribute identification of the skills, knowledge, behaviours and competences required to meet present and future personnel selection demands, in adjustment with the differentiation in approaches and organizational preferences, 2) they can direct the individual and organize improvement plans to eliminate the divergence between the proficiencies requested for a career and those accessible. Today, after ages of finding the first competency represent, more than half of the Fortune 500 enterprises are applying competency modelling [13].

Good governance and accountability issues have developed into an important consideration in Indonesia after the economic crisis and consequent political transformation in 1998. The Indonesian government becomes progressively turned attention to the effort of performance measurement for the governmental agencies, including local authorities, as part of bureaucratic reform and good governance practices [14].

The low competence of government officials, especially government officials, is very much influenced by the recruitment system which is dominated by the central government and the limited local government budget. All this causes several weaknesses on both sides. For the people who will lack quality services, for the government cannot carry out the people's mandate optimally. Officials, as government officials, have the right to develop a career, which cannot develop optimally. On the other hand, the community gets less quality services because the government cannot carry out the mandate optimally. Finally, the progress of the state and nation is hampered. For example, bureaucratic reform in Indonesia could not proceed as expected due to the low competency of the government apparatus so it could not bring significant changes in public services, especially in the regions [15]. 


\section{Kresna Social Science and Humanities Research}

Proceedings of the International Conference On Ummah:

Digital Innovation, Humanities And Economy (ICU: DIHEc) 2020

https:/doi.org/10.30874/ksshr.6

According to the Republic of Indonesia State Personnel Agency Regulation Number 26 of 2019 concerning "Developing Civil Servants Competency Assessment Organizers". The competencies were using many tests for this purposes it depends also with job classification promotion that we assess. For the simple assessment (Supervisor Level /Echelon 4) Serial tests that we used psychological testing (Intelligence, Personality, etc.), Writing an essay (question-based competencies) and Interview. The second for the medium assessment (Manager Level / Echelon 3) we were using All tests Like simple test but we add more test FGD (Focus Group Discussion). The third for complex testing (Director Level / Echelon 2) same like a test before but we add the candidate must be made the proposal on how to make innovation in the department they will become the leader. Finally, for multiple complex testing (CEO level / Echelon 1) the candidate would do the presentation in front of panellist usually we using people from the outside government like academicians, Professionals, Etc. become appraisal. The result for these kinds of tests we could get profiles for potential (Psychological Attribute) and competencies (Skill and Performance Attribute) of the testee.

Levelling Job Discerptions for the Echelons Level In government policy :

1. Echelon 4 needed more ability (technical skill) that managerial skill

2. Echelon 3 more moderate its need equal skill for technical and managerial skill

3. Echelon 2 Focus on managerial skill rater than technical skill

For measuring the job performance will use new development measurement as mandated by Law Number 30 of 2019 concerning civil servants work assessment Performance Evaluation of Civil Servants aims to guarantee the objectivity of the civil servant coaching based on achievement systems and career systems. Performance Assessment of Civil Servants as referred to in Article 2 done based on performance planning at the level individual and unit or organization level, taking into account the targets, achievements, results, and benefits achieved, and the behaviour of civil servants. In this regard, the creation of an innovative model of potential and competencies test of Echelon 3 selection for West Nusa Tenggara Province becomes an aim of scientific research.

In the question of the job performances of a civil servant who elected from potential and competencies test measure from work performance achievement in their offices, where work performance has an appraisal for one year. Moreover, it is important to study civil servants work assessment Performance Evaluation developed, because of this evaluation a new to implement in early 2019, however, has at the end of this year it mean the researcher could collect the Appraisal job performance the echelon 3. In total, this data gives an opportunity to know about how are the competencies test influence job performance in West Nusa Tenggara Province and reach a purpose of research. 


\section{Kresna Social Science and Humanities Research}

Proceedings of the International Conference On Ummah:

Digital Innovation, Humanities And Economy (ICU: DIHEc) 2020

https:/doi.org/10.30874/ksshr.6

\section{Literature Review}

The reference to several competency studies having a significant and influential relationship in improving employee performance and other studies also show the relationship of several potential aspects of individuals such as, intelligence, personality, emotional intelligence, etc. which are significant in improving employee performance:

1. Within the scope of echelon III structural officials of NTB province does the potential and competency test result have a significant effect predicting on performance appraisal.

2. See how much the relationship of factors that measure potential and competency tests has a significant effect on echelon III structural officials performance appraisal.

\subsection{Talent Management}

The term "talent management" turned into prestige in 1997, when the consultancy company McKinsey and the business pointed out to the war for talent. The describes having been applied progressively over the last decade. This represents an understanding of the usefulness adhered to the recruitment and development of high-quality employees for the prosperity of an institution. There are many interpretations of talent management. For some reviews, the entity of Human Resource Management (HRM) is concerned about talent management, which argues that the management of people influences on every feature of HRM. For alternatives, talent management is affected with fostering and examining over the talented few in the organization, who can create the biggest strategic increase now and in the future [16].

Explanation from Binder [17] Talent development puts on the people and his or her career breakthrough within the company. Talent development has the viewpoint of "looking back" at past performance and "looking forward" to future duties. To accomplish this, a talent management plan needs to be closely associated with the company's strategic objectives and organization needs-goal alignment clarifies work tasks and determines current values of the employee to the organization. By making employee ownership in the company's success and high employee engagement, talents are aided to attain the desired high levels of job performance. Organizations that are competent to clarify their exact talent requirements and thus measure and engage them will adequately achieve organizational targets. Employee performance management incorporates and integrates many parts of people management. It is a transform for establishing an experienced understanding about what is to be obtained at an organizational level [18].

The talent and performance management plan establish a unified approach to many areas, such as recruiting, development planning and learning, succession planning, promoting, mentoring, coaching, 


\section{Kresna Social Science and Humanities Research}

Proceedings of the International Conference On Ummah:

Digital Innovation, Humanities And Economy (ICU: DIHEc) 2020

https:/doi.org/10.30874/ksshr.6

and compensation. All these components are essential to reach sustainable and desired results and provide a context for employees to perform at their best [17].

\subsection{Talent Management Policies}

The primary issues in the global approach are whether all talent management policies are needed for all employees. Indeed in the most equitable companies, it is unlikely that all employees will progress through the development centre, and whether there would be detectable career directions for all. However, the flow to exploit new technology in a self-service mode, so that people can extend as far as they like with their retained improvement, perhaps interrupting and pulling up development programmes, later on, drives it probable for high degrees of responsibility for people, without any corporate responsibility to promotion or careers. Nevertheless, the qualities ingrained by the global method may enhance the business strategy and work carry supplementary advances that mean corporate cohesiveness and equity, which should form some extraordinary individuals whose talent would otherwise have been neglected [16].

In a definite view of talent, policies will possibly be further comprehensive, and those individuals classified as high potential may be set on a fast track to development and promotion. There is no vagueness, and there is a wide and fair approach, employees learn what to hope, there is an obvious narrative on how talent management fits into the society philosophy. Where organization have a practical HR procedure, there may be an intelligible set of policies, of a lessened or pervasive description, which are either referred to all under the universal approach, or are covered to precise roles and people. The agreement about what approaches are affected will be efficient, and may shift faster over time, dealing to occurrences. Talent management is motivated wholly by the work force needs at that time [16].

The policy areas that are used in talent management include:

- Identification of competencies

- Career management

- Identifying people for promotion

- Succession planning

- Assessment of general potential

\subsubsection{The Identification of Competencies.}

Competencies necessarily contribute to consideration on careers and potential. In performing the assessment of competencies serves two major purposes: the identification of those who perform to be sufficient for promotion and the assessments of the general potential and competencies of 


\section{Kresna Social Science and Humanities Research}

Proceedings of the International Conference On Ummah:

Digital Innovation, Humanities And Economy (ICU: DIHEc) 2020

https:/doi.org/10.30874/ksshr.6

people in order to determine how their talents may best be employed in the concerns of the organization and of the individuals themselves [19].

If we are planning our people resources adequately we can look at where to classify individuals according to their performance (competencies) and potential ratings, recognizing constantly that these are two axes along which substantial alteration is viable over time, and that categories have a substantial subjective element [16].

There are management decisions about how to deal with these various groups of employees. The 1: 2 low performers (competencies) with no potential should be replaced unless the performance (competencies) lapse is temporary (assuming new starters are not included in this grid). The high performance (competencies) with little potential should be retained and managed to deliver the result on a continuing basis. Those whose performance (competencies) is low but whose potential is high should be developed, and this star with high potential and high performance (competencies) should be rewarded, developed and promoted [16]

Table 1.

Potential vs Performance / competencies Rating [16]

\begin{tabular}{|l|c|c|}
\hline & Develop & Reward/develop/promote \\
P & (High Potential Low Performance) & (High Potential High Performance) \\
$\mathrm{O}$ & & \\
$\mathrm{T}$ & & \\
$\mathrm{E}$ & & \\
$\mathrm{N}$ & & \\
$\mathrm{T}$ & Retain \\
$\mathrm{I}$ & (Low Potential Low Performance) & (Low Potential High Performance) \\
$\mathrm{A}$ & & \\
$\mathrm{L}$ & & \\
& & \\
& & \\
\end{tabular}

\section{PERFORMANCE / COMPETENCIES}

Views on talent or performance vary in method: a more narrow approach is to consider talent in terms of professional and technical skills, knowledge or competences, and performance in terms of productivity. Nowadays, it has developed into essential to adapt a much wider approach. Talent and performance demand to be viewed as an essential contribution to a wide range of factors, for example, company culture, vision, customer satisfaction, and quality of contribution to working in teams. In this adhere to it is important to have the human resources goals-comprising all activities, processes, and projects in this area-aligned with the business strategies of an organization [17]. 


\section{Kresna Social Science and Humanities Research}

Proceedings of the International Conference On Ummah:

Digital Innovation, Humanities And Economy (ICU: DIHEc) 2020

https:/doi.org/10.30874/ksshr.6

\subsubsection{Career Management}

Armstrong [20] said, The evolving environment of careers is one reason why talent management is such a vigorous field. Careers still have a boundaryless nature, and few people will allocate their working life in one organization. The changes in employment style, with unions, acquisitions and public sector restructuring and reduction mean the old 'linear' careers are moved for the tremendous majority of working people. There are now what Hall and Moss [21] called 'protean' careers, where people change their career direction frequently in their working life and in many cases will have no career concept at all. Even in the civil service at senior levels and with specialists, people are brought in for short periods, and civil servants leaves to work in other organizations. Careers are formed between an organization and the people is predicted normally to pick up authority for his or her own career. The improvement of professionals to see their specialism as the causes of their career status, for a case, whether they are engineers working in the oil industry, technicians in the film or television industry, or teachers, lawyers or IT specialists, they see themselves as being in charge of their own destinies [16].

\subsubsection{Identifying staff for Promotion}

The selection of personnel for promotion is, in substance, the same deal with as the selection of new employees. Everything that takes previously been said about the problems of selecting new employees, the limitations of predictive methods and especially the interview, apply equally here and need not be repeated. A job vacancy has to be filled and there is usually a field of several candidates. The requirements and criteria for effective performance at the higher level need to be defined in exactly the same way as for recruitment and selections: the task and problem of the selectors is to predict the candidate's likely behavior in a new job situation [16].

However, there are some important variations between recruitment and promotion situations. In the erstwhile situation, the employing organization is negotiating with unknown people. When choosing staff for promotion, it already has a store of information both formal and informal about candidates. Furthermore, there are important areas in which prediction is not necessary, namely, compatibility with the organizational culture and relationship with colleagues. Nevertheless, example regularly occur of employees who are very effective at one level but prove to be far less successful at the higher level, as if confirming the well know 'Peter principle' that people eventually are promoted to the level of their incompetence (beyond which they will not be promoted because they are failing) [16]. 


\section{Kresna Social Science and Humanities Research}

Proceedings of the International Conference On Ummah:

Digital Innovation, Humanities And Economy (ICU: DIHEc) 2020

https:/doi.org/10.30874/ksshr.6

\subsubsection{Succession Planning}

Succession planning is a part of the career management structure. Instead of determining the precise individual and developing them for the specific situation, the better effective approach is to establish a pool of talented people, with convenient competences, and to present them with the experiences to be sufficient candidates when a vacancy appears. Accordingly, the organization is not susceptible upon one person to be promoted, who may withdraw at a time which is inconvenient. This practice depends upon there being a plentiful number of high-quality candidates who can generate a large suitable variety of skill and abilities to be potentially appointable to the possible roles which may develop into vacant. If those in the pool are abel and are prepared to move somewhere, they will also be targets for 'head hunters', or may not be around for other reason at the critical time when a vacancy occurs [22].

\subsubsection{Assessing General Potential}

The basis of this task is to assess whether employees have the potential to perform the types and levels of performance that are possible to be applicable in the future (at least as far as the end of the field planning period). This assessment bears to be based on the evidence accessible from HR histories, adding performance reviews, development and education records, which are centrally sustained and organized by the HR staff. These records cover a period of several years and extend beyond the confines of the present task. Since the assessment of the general potential of employees is arrayed in the broader organizational background, generally the study is brought out simultaneously by the responsible HR and Line managers [23].

One popular theory that is often helpful for individuals to use comes from professor Ed Schein. He developed the notion of career anchors. A career anchor is 'a combination of perceived are of competence, motives and values that you would not give up, to represent your real self [24]. He identified eight different career anchors : technical/functional competence, general management competence, autonomy/independence, security/stability, pure challenge and lifestyle. The pure challenge career anchor is one when the intellectual challenge is the motivating force, such as for some engineers and consultants. The lifestyle career anchor is concerned with balancing family needs. Work needs and personal needs, in an integrated way. Career anchors are one way of describing the values people have about work, and provide a starting point for a career discussion [24].

\subsection{Potential and Competencies}

A major goal of these chapters is to integrate the study of potential (intelligence, personality, etc) and related skills with the study of competence. Potential tests measure achieved skills or competencies. Achievement does not just depend on abilities, of course. It depends on the interaction of abilities with 


\section{Kresna Social Science and Humanities Research}

Proceedings of the International Conference On Ummah:

Digital Innovation, Humanities And Economy (ICU: DIHEc) 2020

https:/doi.org/10.30874/ksshr.6

other key attributes of the person. Consider a model for how basic skills or abilities are translated into achievement [25].

According to Armstrong and Taylor [23] Behavioural competency modelling is the transform applied for determining, analysing and describing behavioural competencies which define the behaviours that organizations require their personnel to work out in their work to achieve a sufficient level of performance. They have a great part to perform in contributing knowledge which contributes to several HRM schemes, for example, recruitment, learning and development, and Performance Appraisal.

\subsubsection{How to Assesses Potential and Competencies.}

The assessment centre (Competencies) and Psychometric test (Potential) are likewise applied for promotion and development purpose. Growing use has been made of an assessment centre for assessing the potential candidates for employment and that of existing employees. They are used mainly for finding personnel, especially managers, who demonstrate the potential for growth to senior positions. These centres may be organized internally by the organization, or they may be external, suggesting an assessment service to all organization that hopes to deliver personnel for testing. The internal organizational centre will commonly be staffed by seniors managers of the organization, educated in the methods of the centre and by an occupational psychologist. The external organization requiring this function will generally be staffed by an occupational psychologist [16].

Edenborough [26] said On the basis of the model already described for making systematic judgements, the first task of the assessment center is to define the required competencies. For example a process for assessing managerial potential might be based on the following criteria :

1. Personal attributes : self-confidence, emotional stability, resilience, breadth of vision, flexibility and adaptability, sociability and cooperativeness, sense of humor, tolerance and patience, balanced views, personality which can make impact, moral courage, management ability and readiness to learn.

2. Competence in practice : analytical and reasoning powers, problem-solving and decision-making skill, identification of priorities, planning and organizing abilities, team membership skill, leadership and communication skill.

The methods commonly used to test and reveal these attributes and competencies are

- Psychometric tests of intelligence, aptitude and personality

- Group situational tests involving problem-solving and decision-making exercises 


\section{Kresna Social Science and Humanities Research}

Proceedings of the International Conference On Ummah:

Digital Innovation, Humanities And Economy (ICU: DIHEc) 2020

https:/doi.org/10.30874/ksshr.6

- Leadership and team membership role-play exercises

- Presentation to group members

- Individual, written and oral problem solving exercises

- Exercises to tests mental, emotional and physical characteristics. These could outdoor exercises.

\subsubsection{The Potential Review.}

Psychometric tests have a history that, although not long, moves back further than is generally realized. They found in work connected to education in the latter part of the 19th century. Binet and another associate, Simon, in 1905 a physiologist by training, he carried out the first methodical attempt to define mental phenomena on a scientific basis. Among the disciplines strengthened by these laboratories-based approaches were those of standardization of procedures. These carried the same stimuli tested under the same conditions, with set orders, recording of responses and common methods of interpretation. However, though deeply systematic in his approach his work was immensely dependent on reported sensations [26].

Publication by a trustworthy publisher, although certainly not a distinguishing attribute of psychometrics, is one rather reliable guide. It should be mentioned though that many competent and respectable testing methods are also produced within commercial organizations or university departments. Bodies such as the Civil Service have operated with their own test batteries for many years. In all processes, the typical standard has included processes of research to test out the individual items and then gathering these together in a whole test [26].

In the practice of personnel selection, there are many different methods that may be used, as listed below [16]:

1. Ability tests of achievement: These are worked out to test what the applicant already experiences or can do, relative to the qualifications of the job (e.g. skills in riding, instrument skills, programs languages, knowledge of psychology, antique goods).

2. Ability tests of aptitude: These are formed to predict latent potential to meet job requirements, which can be developed to required standards by education and experience. Aptitude tests may have intelligence tests, designed to measure a broad range of generally applicable abilities, or more specialized tests, designed to indicate particular aptitudes, e.g. mechanical skills. The ability tests included under this heading are too numerous and varied in purpose to enumerate. 


\section{Kresna Social Science and Humanities Research}

Proceedings of the International Conference On Ummah:

Digital Innovation, Humanities And Economy (ICU: DIHEc) 2020

https:/doi.org/10.30874/ksshr.6

3. Tests of personality: traits of personality definitely have a profoundly important effect on the performance of work, and specifically any kind of managerial work, where judgement, and influence on and relationships with others, are crucial. A number of tests have been developed and used by psychologists over the years in an attempt to determine personality characteristics as a basis for predicting likely future behaviour at work.

It is particularly important to the validity of the system that occurs should be followed up. This measures that the selectors require to have a regular flow of feedback from line executives reporting how effectively selected employees are actually performing. These data can then be used to trace and remedy weaknesses in the selection process. Formal validation studies are rare, but some organizations do analyse promotion performance, and sometimes performance appraisal, to check the effectiveness of selection decisions [16].

\subsubsection{The Competencies Review.}

A competency is defined as a capability or ability. It is a set of associated but distinct sets of behavior organized around a guiding design which we call the "intent". The behaviors are varied indications of the intent, as applicable in various situations or times. For illustration, listening to someone and asking him or her queries are several behaviors. An individual can determine these actions for numerous reasons or to various expected ends. A person can ask questions and take notice to someone to ingratiate him or herself or to show involved, thereby obtaining standing in the other person's view. Or an individual can ask questions and listen to someone because he or she is excited in figuring out this other person, his or her priorities, or concerns in a situation. The latter we would claim a manifestation of empathy. The basic intent is to understand the person. Meanwhile, the erstwhile determined reason for the questions is to obtain belief or impact in the person's view, aspects of what we may note an expression of influence. Similarly, the elemental intent of a more sophisticated competency like Emotional SelfAwareness is self-insight and self-understanding [27].

This development of competencies as involving both action (i.e. a set of alternate behaviors) and intent called for measurement methods that allowed for an assessment of both the existence of the behavior and inference of the intent. A modification of the critical incident interview Flanagan [28] was accustomed applying the analysis sequence from the Thematic Apperception Test and the concentrate on specific events in one's life 


\section{Kresna Social Science and Humanities Research}

Proceedings of the International Conference On Ummah:

Digital Innovation, Humanities And Economy (ICU: DIHEc) 2020

https:/doi.org/10.30874/ksshr.6

from the biodata method [29]. Later, informant assessment through 360 or assessment center and simulations coded by reliable "professionals" are fundamental. This is a behavioral approach to a person's talent [27].

The anchor for learning which behaviors and which intent is related in a situation appears from predicting performance. The development of the individual competency is a means of connecting different behaviors that are considered alternate manifestations of the same basic construct. But they are organized primarily or more accurately initially, by the similarity of the concern of the practice of these behaviors in social or work settings [27]. An understanding of performance is the essential for the concept of competency. The theory adopted in this method is a basic contingency theory, as presented in Diagram 1. Maximum performance is expected to result when an individual's capability or talent is consistent with the demands of the job requests and the organizational environment [30]. The person's talent is characterized by his or her: values, vision, and personal philosophy; knowledge; competencies; life and career stage; interests; and style. Job demands can be represented by the role duties and tasks needed to be performed. Aspects of the organizational environment that are predicted to have a significant impact on the expression of competencies and/or the model of the jobs roles include: culture and climate; structure and systems; maturity of the industry and strategic positioning within it; and aspects of the economic, political, social, environmental, and religious milieu surrounding the organization.

\section{DIAGRAM 1.}

Theory of action and job performance [27].

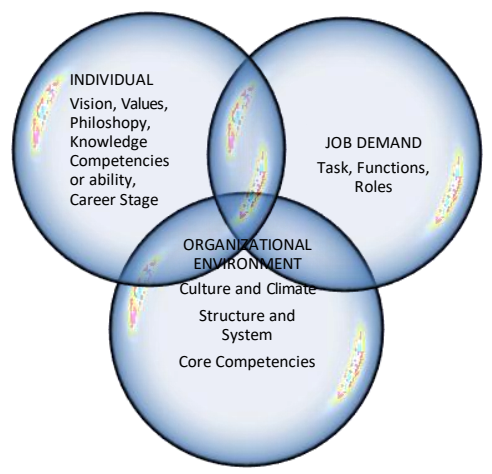




\section{Kresna Social Science and Humanities Research}

Proceedings of the International Conference On Ummah:

Digital Innovation, Humanities And Economy (ICU: DIHEc) 2020

https:/doi.org/10.30874/ksshr.6

To be a competent leader, executive or professional, an individual needs the ability to manage knowledge and to make things appear. These can be called competencies, which Boyatzis [30] defined as, "the underlying characteristics of a person that lead to or cause effective and outstanding performance". Whether informed experimental research is reported from other articles in this particular issue or the past literature [30-35] or metaanalytic syntheses are used [36-38], there are a set of competencies that have been shown to cause or predict outstanding leader, manager or professional performance. Regardless of author or study, they tend to include abilities from three clusters:

1. Cognitive intelligence competencies, such as systems thinking;

2. Emotional intelligence competencies, or intrapersonal abilities, such as adaptability; and

3. Social intelligence competencies, or interpersonal abilities, such as networking.

\subsection{Performance Appraisal}

Historically, performance appraisal in the UK found mainly in the public sector of employment - the armed forces and the Civil Service. Now, formal methods of performance appraisal are universally applied in the majority of employment organizations in both the public and private sectors. The details of these formal patterns range considerably, depending on the purposes and preferences of individual work organizations. These differences are followed in describes of the scheme of reports, degrees of confidentiality and openness, who supervises the appraisal, the level of presence by those being appraised, the essence of appraisal discussions between those appraising and those being appraised, and how the report is used, for example in rewards, promotion and training decisions [16].

Performed by the employees. In this understanding, employee performance appraisal is the proper measures to conduct detailed analyses of the employees' performance. To obtain an adequate level of performance, it is necessary to take into detail the individual personalities and capabilities of an employee, the resolutions made forth by the employees, and the achievement of recognition of their act. Therefore, it is remarkable to note that whatever scheme of performance appraisal an organization practices, it must be task related. Accordingly, previous to preferring a performance appraisal method, job analyses must be managed and job descriptions developed and refined to keep up with the company's recent changes [18]. Performance appraisal is an extensively practiced device for human resources management. Originally used as a tool for managers, it is now used to evaluate the performance of guided, secretarial and administrative staff and part-time staff in the public and private sectors. 


\section{Kresna Social Science and Humanities Research}

Proceedings of the International Conference On Ummah:

Digital Innovation, Humanities And Economy (ICU: DIHEc) 2020

https:/doi.org/10.30874/ksshr.6

Traditionally appraisals were conducted by supervisors, nevertheless in recent years there has been an expansion in the range of people who are able to provide data and make assessments of an employee's performance [39].

\subsection{Frame Work}

Framework thinking is a conceptual model that is used to clarify the position of variables used in research. This model tries to describe the performance of employees with Potential, Competencies and both of that variables where it can be seen that this factor can play an important role in the process of improving employee performance. This researcher proves these factors as one of the important components in improving employee performance. The concepts developed in this study are formed in the following models:

\section{DIAGRAM 2.}

\section{Framework}

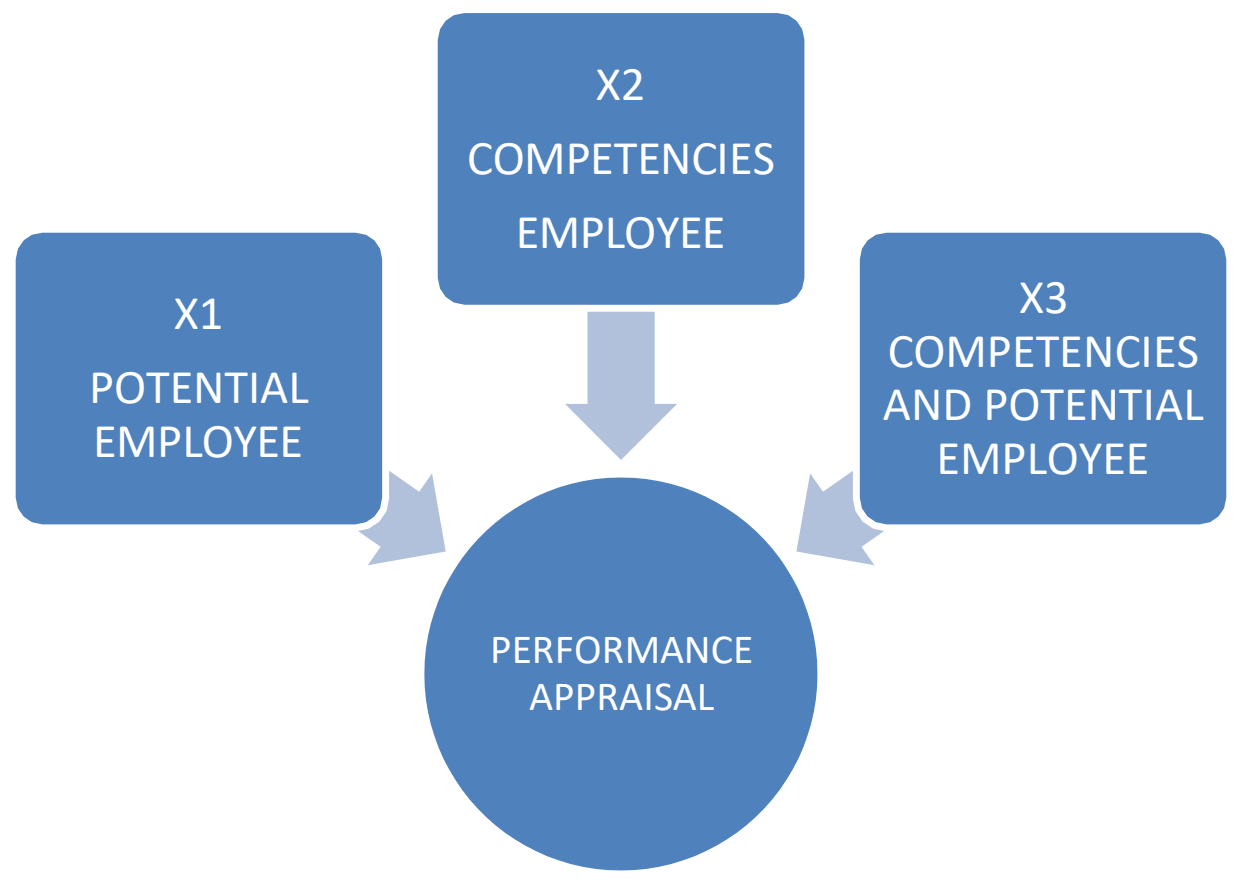

The conceptual framework of this research [16, 40, 41]

\subsection{Hypothesis}

Beyond knowledge and competencies, the other factor crucial to exceptional performance comes out to be the motive to exploit one's talent. This seems motivated by an individual's values, philosophy, sense of order or mission, instinctive motives and traits [40,42]. The concepts and attributes affect both the style of somebody views the world, specifically the perception of opportunities and challenges they discern in the surrounding. But they likewise are enduring and generalized drivers. They arouse 


\section{Kresna Social Science and Humanities Research}

Proceedings of the International Conference On Ummah:

Digital Innovation, Humanities And Economy (ICU: DIHEc) 2020

https:/doi.org/10.30874/ksshr.6

dispositional moves a person reacts to his/her environment and construct a concentrate for a person's behavior[19].

These three spheres of competence or talent (i.e. knowledge, competencies, and motivational drivers) support us to figure out what an individual can achieve (i.e. knowledge), how a person can work it (i.e. competencies), and why a person knows the need to do it (i.e. values, motives, and unconscious dispositions). Our task in HR or government personnel agency is to help people add value on each of these domains - to help them to prepare to be effective in their future jobs and careers [19].

From all perspective above Researcher developed hypotheses :

1. H1 : Potential Result Has a Positive Influence on Performance Appraisal Echelon III Officials West Nusa Tenggara Province.

2. H2 : Competencies Result Has a Positive Influence on Performance Appraisal Echelon III Officials West Nusa Tenggara Province.

3. H3 : Potential and Competencies Result have Simultaneously a Positive Influences on Performance Appraisal Echelon III Officials West Nusa Tenggara Province

\section{Methodology Research}

Persistence of the type of research is required to carry out it simpler to determine the most relevant method of obtaining information to figure out the problem under consideration. According to EasterbySmith, et al. [43] that by identifying the types of research, the scientist can designate the most practical and decisive method to obtain a report that will be used to clarify the obstacle understudy.

In this study is quantitative with a descriptive analysis including data got from the field or sampling population to be analyzed and presented a statistical interpretation in accordance with the method chosen. By involving quantitative methods of information gathering. According to Easterby-Smith, et al. [43] contends that the results can provide for the range of each demanded in the situation of compound feedbacks and concerns of each individual, in this research applying quantitative methods that can be studied more effective and efficient.

The cross-sectional design is generally applied in quantitative studies [44], this approach provides relations to determine between varied aspects. The cross-sectional design makes comparisons at one point in time [43], because of the time limit the researcher has, cross-sectional design choices are made. When developing a research design, it is necessary to examine depending on the research objectives and research can be distinguished in certain ways.

Cross-sectional method is decisive in investigating and understanding the relationship of questions with the determinants measured at a time or period to define the performance of echelon III officials of the government of West Nusa Tenggara province with the factors identified with it, particularly the potential 


\section{Kresna Social Science and Humanities Research}

Proceedings of the International Conference On Ummah:

Digital Innovation, Humanities And Economy (ICU: DIHEc) 2020

https:/doi.org/10.30874/ksshr.6

variables consisting of intelligence, analytical power, logic of thought, systematic thinking, decision making, self-confidence, motivation, etc. While competency variables consist of an analysis of strategy, visionary initiative, enthusiasm for achievement, planning and organization, written communication, Etc.

Conceptually, the framework of this study was built based on the theory of potential and competencies McClelland [41]. Based on this theory, the researcher got knowledge that the two factors, especially a person's potential and competence, were intimately connected to employee performance. The Occupational Potential and Competency development was initiated by David McClelland in the 1960s with a regard to changing elsewhere from conventional attempts to describe Potential and competency in terms of knowledge, skills and attitudes and to concentrate instead on the specific self-image, values, traits, and motive dispositions (i.e. comparatively enduring characteristics of people) that are found to typically discriminate superior from ordinary performance in a given job or role. Different Potential and competencies predict outstanding performance in different roles.

Boyatzis [27] defined Potential and competency principally as an elemental essence that could be a motive, trait, skill, an aspect of their personality-perception or social performance, or body of knowledge which they use. Boyatzis distinguishes between functions, tasks and relevant potential and competences. Furthermore, potential and competency are an elemental component of an individual in that it may be a motive, trait, skill, aspect of one's self-image or social role, or a body of knowledge which he/she uses. The presence and custody of these qualities may or not be recognized by the individual. In this understanding, the characteristics defined to be important aspects of the Individual job performance. Because job performance is determining essences, they related to potential and competencies a person. Job performance may be apparent in many forms of behaviour, or a wide variety of different actions.

This variable is this variable which is the effect caused by the independent variable. This research uses employee performance appraisal become dependent variables. Employee performance is how well an employee performs his duties and responsibilities. Employee performance is also very important because the achievement of organizational goals and objectives is assessed by performance. With the employee performance appraisal as dependent variable explained, the indicator used according to government regulation number 30 the year 2019 regarding the performance appraisal of civil servants. 


\section{Kresna Social Science and Humanities Research}

Proceedings of the International Conference On Ummah:

Digital Innovation, Humanities And Economy (ICU: DIHEc) 2020

https:/doi.org/10.30874/ksshr.6

The independent variable is variables that affect or which cause it to occur change or onset of the dependent variable. For independent variables, basically these variables will bring changes that bring the results of the data in a research process. The Independent variable used in this research are Potential and competencies employee.

\section{Data Analysis}

This research will be conducted in the government of West Nusa Tenggara Province within a duration of 1 (one) year from January 2019 to December 2019, because all data needed for determining potential, competence (independent variable) and performance Appraisal (dependent variable) are collected within the period that time.

The population is an analysis field consisting of objects and subjects that have specific conditions and peculiarities worked out by researchers to be pored over and then taken inferences. The population in this study were all echelon III officials based on the West Nusa Tenggara (NTB) Province Employee Agency data, the number of echelon III positions in the NTB Provincial Government are 282 positions.

Easterby-Smith, et al. [43] said that the size of the study sample must not be less than $10 \%$ of the population. Based on this, the sample used in this study is as follows :

\section{Sample $=\frac{10}{100} X$ Total Population}

Sample $=\frac{10}{100} X 282=28,2$

We could count become 30 People, Setting the number of more samples is always better than less [44]. This means that the more samples were taken the better. Based on this opinion, the size of the sample taken in this study is 60 people or $20 \%$ of the population. The sample used by respondents is sufficiently representative or already represents the entire population and exceeds the minimum target of $10 \%$.

Data analysis in this study (Univariate, Bivariate and Multivariate analysis) uses computerized data processing for the Statistical Package for the Social Sciences (SPSS) program. Univariate analysis is used to get a picture of the frequency distribution of all research variables.

Regression analysis is a mathematical model that can be used to determine the relationship between 2 (two) or more variables. The purpose of regression analysis is to estimate (predict) the value of employee performance appraisal variables (dependent variables) through potential factors (Intellectual, Work attitude, Personality, and Leadership) Competency factors (Personal, Work, Interpersonal and Managerial) both of these factors are independent variables. 


\section{Kresna Social Science and Humanities Research}

Proceedings of the International Conference On Ummah:

Digital Innovation, Humanities And Economy (ICU: DIHEc) 2020

https:/doi.org/10.30874/ksshr.6

Multiple linear regression equation test, this analysis is used to find out how much influence the independent variables are: potential factors (X1) (Intellectual (X1.1), Work attitude (X1.2), Personality (X1.3) and Leadership (X1. 4)) and Competency factors (X2) (Personal (X2.1), Work (X2.2), Interpersonal (X2.3) and Managerial (X2.4)) on the dependent variable is the value of employee Performance appraisal (Y).

\section{Result}

The researcher will explain the results of research conducted in the NTB provincial government on the assessment of the performance Appraisal of structural officials of Echelon III (administrator / Manager) in 2019 by looking at the effect of the results of potential and competency tests conducted before they are officially appointed as Echelon III officials (selection process). Is there any influence on the selection results on the current performance.

The results of the study illustrate starting from the Univariate analysis covering the frequency distribution of characteristics of the variables related to the performance evaluation of echelon III officials of West Nusa Tenggara (NTB) provincial government. The researcher also conducted a Bivariate analysis to see the relationship between the Independent and Dependent variables with the Regression method. Furthermore, the researcher also conducted a Multivariate analysis to see the relationship between 2 (two) Independent Variables (potentials and competencies) simultaneously on the Dependent Variables (performance appraisal), and see which variable was the most dominant to have an influence by using Multiple Linear Regression analysis. The data tabulation using Statistical Product and Service Solutions (SPSS) Application version 26 (twenty six).

\subsection{Reliability Analysis}

In this research, it was determined the reliability of the Variables that measure the Potential and Competencies of Echelon III Officers, by using a Cronbach's Alpha. The reliability of a measure indicates the internal consistency with which the instrument measures the idea and helps to evaluate the 'goodness' of a measure [45]. In the present study, for those variables, it were achieved a Cronbach's Alpha of 0.703 (Potential Variable) and 0.912 (Competencies Variable) . Brandt and Brandt [45] say if the values are greater than 0.9 are 'very good'. In conclusion, the result showed that the score of Cronbach's Alpha indicates that the measurement Variables of the Potential and Competencies construct was stable and consistent.

\subsection{Classic Assumption for Regression}

There are some fundamental mistakes that often occur in researchers who are still early learning to research. Especially those who are still beginning to get acquainted with simple Regression and multiple linear Regression, which is first to test the classical assumptions and then do the Regression test. Of the 


\section{Kresna Social Science and Humanities Research}

Proceedings of the International Conference On Ummah:

Digital Innovation, Humanities And Economy (ICU: DIHEc) 2020

https:/doi.org/10.30874/ksshr.6

many assumptions, only a few must be done first, such as the assumption of normality, the assumption of linearity and the assumption of multicollinearity before the regression test. While the other assumptions must be after a regression test. The reason is that the outlier, homoscedasticity and autocorrelation tests use error values or residuals as parameters [45].

1. Normality Assumption

Normality Test is a test conducted with the aim to assess the distribution of data in a group of data or variables, whether the data distribution is normally distributed or not. Based on the empirical experience of a number of statistical experts, data with more than 30 numbers $(n>30)$ can be assumed to be normally distributed [45].

2. Linearity Assumption

Linearity is the nature of a linear relationship between variables, meaning that every change that occurs in one variable will be followed by a change in the amount that is parallel to the other variables. Linear model means that the pattern of relations between the two independent and dependent variables will form a straight line. The interpretation is see the Sig. in the Linearity row in the Table, if the value $<0.05$ then it is linear so that it can be concluded that it meets the linearity requirements

Table 1.

Linearity Assumption Value

\begin{tabular}{|c|l|c|c|}
\hline No & \multicolumn{1}{|c|}{ Variables } & F Value & Sig. \\
\hline 1. & Performance Appraisal and Potential & 7.865 & 0.008 \\
\hline 2 & Performance Appraisal and Competencies & 24.359 & 0.000 \\
\hline
\end{tabular}

OUTPUT SPSS 26

3. Multicollinearity Assumption

The purpose of using the Multicollinearity test in research is to test whether the Regression model found a correlation (Strong Relationship) between independent variables. A fit regression model should not occur a correlation between independent variables or Multicollinearity manifestations do not occur. To detect the presence or absence of multicollinearity in the regression model, it can be done in several ways, namely:

1. Seeing the Correlation between Independent variables

2. See the condition index and eigenvalue values

3. See the value of tolerance and variant inflating factor (VIF)

Table 2.

Multicollinearity Assumption Value

\begin{tabular}{|c|lc|c|c|}
\hline No & \multicolumn{1}{|c|}{ Variables } & Tolerance & VIF \\
\hline 1. & Potential & 0.999 & 1.001 \\
\hline
\end{tabular}




\section{Kresna Social Science and Humanities Research}

Proceedings of the International Conference On Ummah:

Digital Innovation, Humanities And Economy (ICU: DIHEc) 2020

https:/doi.org/10.30874/ksshr.6

\begin{tabular}{|l|l|l|l|}
\hline 2 & Competencies & 0.999 & 1.001 \\
\hline
\end{tabular}

OUTPUT SPSS 26

If the tolerance value is greater than 0.10 , it means that there is no multicollinearity and vice versa. Whereas for the VIF value $<10.00$, it means that there is no multicollinearity in the regression model, and vice versa

\subsection{Univariate Result}

To get an overview of research variables, both dependent and independent variables were processed by using univariate analysis. In this study, there are 11 (eleven) variables with numerical data: Performance Appraisal, Intellectual, work attitude, Personality, Leadership, Potential, Personal competencies, Work Competencies, Interpersonal, Managerial and Competencies. There are two categorical data variables, those are gender and respondent age. For numerical data, the mean, median, standard deviation, minimum, maximum, and confident interval values are used. While categorical data types explain variables based on the number and percentage of each group.

Table 3.

Descriptive Performance Appraisal Variable (Dependent)

\begin{tabular}{|c|l|c|c|c|c|}
\hline No. & Variables & $\begin{array}{c}\text { Mean } \\
\text { Median }\end{array}$ & SD & $\begin{array}{c}\text { Minimum } \\
\text { Maximum }\end{array}$ & \\
\hline 1. & Performance Appraisal & 85.642 & 4.504 & 70.00 & 84.478 \\
& & 86.370 & & 92.45 & 86.805 \\
\hline
\end{tabular}

OUTPUT SPSS 26

The average Performance Appraisal of Echelon III Officials of NTB Province was 85,642 (95\% CI $84,478-86,805$ ), a median in value 86,370 with a standard deviation of 4,504 . The lowest score on Performance Appraisal is 70.00 and the highest value on Performance Appraisal is 92.45. From the interval estimation results, it can be concluded that $95 \%$ is believed that the average Performance Appraisal of Echelon III Officials is between 70.00 and 92.45.

Table 4.

Performance Appraisal Echelon III Officials

\begin{tabular}{|c|c|c|}
\hline Performance Appraisal & Summarizes & Percentage \\
\hline Very Poor & 0 & 0 \\
\hline Poor & 1 & 1.7 \\
\hline Decent & 52 & 86.7 \\
\hline Good & 7 & 11.7 \\
\hline Very Good & 0 & 0 \\
\hline
\end{tabular}




\section{Kresna Social Science and Humanities Research}

Proceedings of the International Conference On Ummah:

Digital Innovation, Humanities And Economy (ICU: DIHEc) 2020

https:/doi.org/10.30874/ksshr.6

\begin{tabular}{|c|c|c|}
\hline Total & 60 & 100 \\
\hline
\end{tabular}

\section{OUTPUT SPSS 26}

The performance of Echelon III officials of NTB Province which had a low performance of $1.7 \%$, while decent performers ranked $86.7 \%$ and for good performers had a figure of $11.7 \%$. On the other hand, officials who perform very low and very good are not found or $0 \%$.

Table 5.

Descriptive Variables With Numerical Data

\begin{tabular}{|c|c|c|c|c|c|}
\hline No & Variables & $\begin{array}{c}\text { Mean } \\
\text { Median }\end{array}$ & SD & $\begin{array}{l}\text { Minimum } \\
\text { Maximum }\end{array}$ & CI \\
\hline 1. & Potential & $\begin{array}{l}41.466 \\
41.500\end{array}$ & 5.212 & $\begin{array}{l}33.00 \\
57.00\end{array}$ & $\begin{array}{l}40.120 \\
42.813\end{array}$ \\
\hline 2. & Competencies & $\begin{array}{l}36.116 \\
36.000\end{array}$ & 3.081 & $\begin{array}{l}27.00 \\
48.00\end{array}$ & $\begin{array}{l}35.320 \\
36.912\end{array}$ \\
\hline 3. & Intellectual & $\begin{array}{l}13.250 \\
14.500\end{array}$ & 3.378 & $\begin{array}{c}7.00 \\
20.00\end{array}$ & $\begin{array}{l}12.377 \\
14.122\end{array}$ \\
\hline 4. & Work Attitude & $\begin{array}{l}12.083 \\
12.000\end{array}$ & 1.898 & $\begin{array}{c}9.00 \\
17.00\end{array}$ & $\begin{array}{l}11.593 \\
12.573\end{array}$ \\
\hline 5. & Personality & $\begin{array}{l}11.050 \\
11.000\end{array}$ & 1.032 & $\begin{array}{c}9.00 \\
13.00\end{array}$ & $\begin{array}{l}10.783 \\
11.316\end{array}$ \\
\hline 6. & Leadership & $\begin{array}{l}5.083 \\
4.000\end{array}$ & 2.279 & $\begin{array}{c}2.00 \\
10.00\end{array}$ & $\begin{array}{l}4.494 \\
5.672\end{array}$ \\
\hline 7. & Personal & $\begin{array}{l}5.800 \\
6.000\end{array}$ & 0,839 & $\begin{array}{l}4.00 \\
8.00\end{array}$ & $\begin{array}{l}5.583 \\
6.016\end{array}$ \\
\hline 8. & Work Competencies & $\begin{array}{l}11.966 \\
12.000\end{array}$ & 1.040 & $\begin{array}{c}8.00 \\
16.00\end{array}$ & $\begin{array}{l}11.697 \\
12.235\end{array}$ \\
\hline 9. & Interpersonal & $\begin{array}{l}9.216 \\
9.000\end{array}$ & 0.715 & $\begin{array}{c}8.00 \\
12.00\end{array}$ & $\begin{array}{l}9.031 \\
9.401\end{array}$ \\
\hline 10. & Managerial & $\begin{array}{l}9.133 \\
9.000\end{array}$ & 0.929 & $\begin{array}{c}7.00 \\
12.00\end{array}$ & $\begin{array}{l}8.893 \\
9.373\end{array}$ \\
\hline
\end{tabular}

\section{OUTPUT SPSS 26}

The average potential test score for echelon III officials in NTB Province was 41,466 (95\% CI: 40,120 - 42,813), the median was 41,500 . The lowest value is 33 and the highest value is 57 . From the interval estimation results, it can be concluded that $95 \%$ is believed that the average value of echelon III officials is between 40,120 to 42,813. The average Competencies assessment record for echelon III officials in 


\section{Kresna Social Science and Humanities Research}

Proceedings of the International Conference On Ummah:

Digital Innovation, Humanities And Economy (ICU: DIHEc) 2020

https:/doi.org/10.30874/ksshr.6

NTB Province was 36.116 (95\% CI: 35.320 - 36.912), the median was 36.000. The smallest value is 27 and the greatest value is 48 . From the interval appraisal comes from, it can be determined that $95 \%$ is considered that the average rate of echelon III officials is between 35.320 to 36.912 .

Table 6.

Categories Data Distribution Respondent

\begin{tabular}{|c|c|c|c|}
\hline No & \multicolumn{1}{|c|}{ Variables } & $\begin{array}{c}\text { SUM } \\
\mathrm{N}=60\end{array}$ & Percentage \\
\hline 1. & Gender & & \\
& 1. Man & 46 & 76.7 \\
& 2. Women & 14 & 23.3 \\
\hline 2. & Age & 6 & 10 \\
& $1 .<40$ & 6 & 10 \\
& $2.41-43$ & 7 & 11.7 \\
& $3.44-47$ & 13 & 21.7 \\
& $4.48-50$ & 28 & 46.7 \\
\hline
\end{tabular}

OUTPUT SPSS 26

Gender distribution data of echelon III officials in NTB province for males 46 (76.7\%) while for females 14 (23.3\%). Age distribution data for echelon III officials of NTB province, for ages <40 years $6(10 \%)$, 41-43 years $6(10 \%), 44-47$ years $7(11.7 \%), 48-50$ years $13(21.7 \%)$, and 50+ years $28(46.7 \%)$.

\subsection{Bivariate Result}

To find out the relationship between dependent and independent variables of each variable, then Pearson's Correlation Test and Simple Linear Regression analysis are used.

Table 7.

Correlation analysis and Simple Linear Regression Result

\begin{tabular}{|l|c|c|c|c|}
\hline \multicolumn{1}{|c|}{ Researches Variables } & $\mathrm{R}$ & $\mathrm{R}^{2}$ & Lines Of Equation & $\begin{array}{c}\mathrm{P} \\
\text { Value }\end{array}$ \\
\hline $\begin{array}{l}\text { Performance Appraisal(Y) and } \\
\text { Potential (X1) }\end{array}$ & 0.370 & 0.137 & $\mathrm{Y}=72.384+0.320$ & 0.004 \\
\hline $\begin{array}{l}\text { Performance Appraisal (Y) and } \\
\text { Competencies (X2) }\end{array}$ & 0.513 & 0.263 & $\mathrm{Y}=58.558+0.750$ & 0.000 \\
\hline
\end{tabular}

OUTPUT SPSS 26 


\section{Kresna Social Science and Humanities Research}

Proceedings of the International Conference On Ummah:

Digital Innovation, Humanities And Economy (ICU: DIHEc) 2020

https:/doi.org/10.30874/ksshr.6

The results of the analysis in this study indicate that the relationship of Potential Variables with the performance of Echelon III officials of NTB Province shows a moderate relationship (0.370) and is positively patterned, meaning that the greater the potential official's, the more likely it is to affect the high performance. The coefficient value with a determination of 0.137 means that the obtained regression line equation can explain $13.7 \%$ variation in performance or the obtained line equation is good enough to explain the performance variable. Statistical test results found that there is a significant relationship between potential and performance $(\mathrm{p}=0.004)$.

From this analysis Researcher proven Hypothesis 1 that stated Potential Result Has a Positive Influence on Performance Appraisal Echelon III Officials West Nusa Tenggara Province.

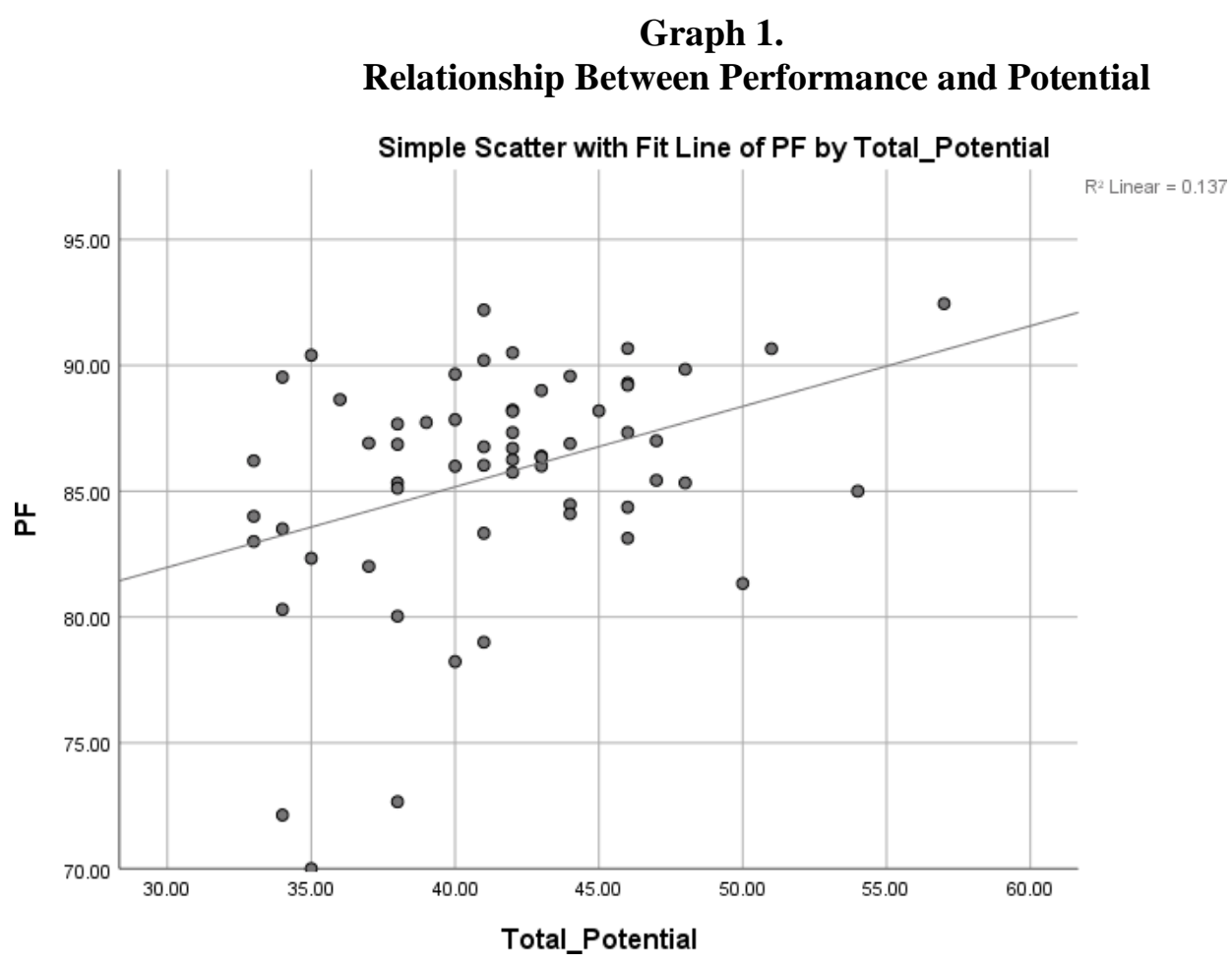

OUTPUT SPSS 26

The results of the analysis in this research demonstrate that the relationship of Competencies Variables with the performance of Echelon III officials of NTB Province shows a Strong relationship (0.513) and is positively shaped, effect that the higher the Competencies official's, the better possible it is to influence the great Performance. The coefficient value with a determination of 0.263 means that the achieved regression line equation can describe $26.3 \%$ divergence in performance or the realized line equation is reliable sufficient to spell out the performance variable. Statistical test results found that 


\section{Kresna Social Science and Humanities Research}

Proceedings of the International Conference On Ummah:

Digital Innovation, Humanities And Economy (ICU: DIHEc) 2020

https:/doi.org/10.30874/ksshr.6

there is a significant relationship between Competencies and performance $(p=0.000)$.

From this analysis Researcher proven Hypothesis 2 that stated Competencies Result Has a Positive Influence on Performance Appraisal Echelon III Officials West Nusa Tenggara Province.

Graph 2.

Relationship Between Performance and Competencies

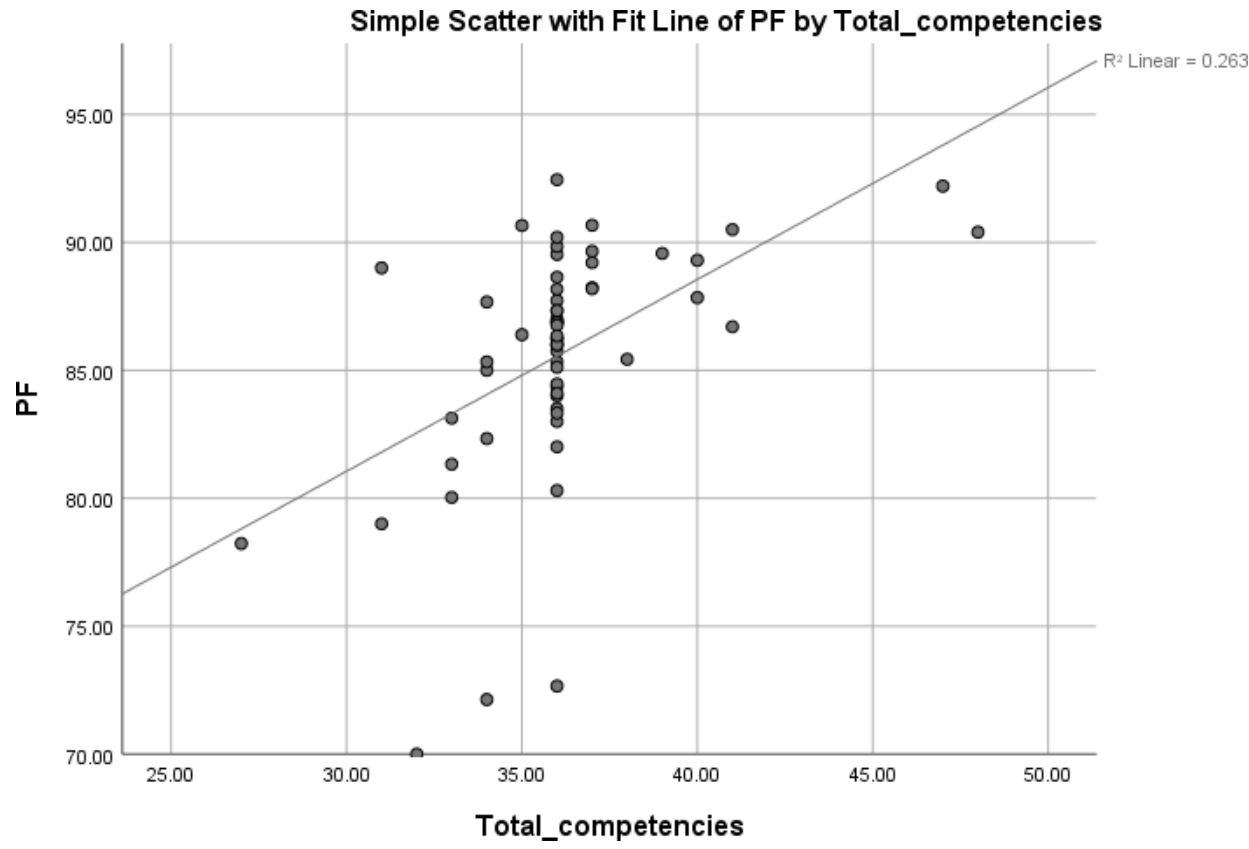

OUTPUT SPSS 26

\subsection{Multivariate Result}

Multivariate analysis is a method of processing variables in more than one number, where the aim is to look for the influence of these variables on an object simultaneously. It is assumed that these variables are related to one another[45]. To test the hypothesis in this study multivariate analysis will be used multiple linear regression method to look for the influence of two independent variables Potential (X1) and Competence (X2) on the dependent variable Performance Appraisal (Y).

Table 8.

Multivariate Model Research

\begin{tabular}{|l|c|c|c|}
\hline \multicolumn{1}{|c|}{ Model } & $\mathrm{R}$ & $\mathrm{R}^{\mathbf{2}}$ & $\mathrm{P}$ Value Anova \\
\hline 1 & 0.640 & 0.410 & 0.000 \\
\hline
\end{tabular}

\section{OUTPUT SPSS 26}




\section{Kresna Social Science and Humanities Research}

Proceedings of the International Conference On Ummah:

Digital Innovation, Humanities And Economy (ICU: DIHEc) 2020

https:/doi.org/10.30874/ksshr.6

Table 9.

Coefficients Variables Research

\begin{tabular}{|l|c|c|c|c|c|}
\hline \multirow{2}{*}{ Variables } & \multicolumn{2}{|c|}{$\begin{array}{c}\text { Unstandardized } \\
\text { Coefficients }\end{array}$} & $\begin{array}{c}\text { Standardized } \\
\text { Coefficients }\end{array}$ & $\mathrm{t}$ & \multirow{2}{*}{} \\
\cline { 2 - 5 } & $\mathrm{B}$ & Std. Eror & Beta & & \\
\hline Potential & 0.331 & 0.088 & 0.383 & 3.767 & 0.000 \\
\hline Competencies & 0.764 & 0.149 & 0.523 & 5.138 & 0.000 \\
\hline
\end{tabular}

\section{OUTPUT SPSS 26}

The results of the analysis in this research demonstrate that the relationship of Potential and Competencies Variables with the performance of Echelon III officials of NTB Province shows a simultaneously Strong relationship (0.640) and is positively shaped, meaning that the higher the Potential and Competencies official's, the better possible it is to influence the great Performance. The coefficient value with a determination of 0.410 means that the achieved regression line equation can describe $41 \%$ Variation in performance or the realized line equation is reliably sufficient to explain the performance variable. Statistical test results found that there is a significant relationship between Potential and Competencies (Independent Variables) towards performance (Dependent Variable) ( $\mathrm{p}=$ $0.000)$.

From this analysis Researcher proven Hypothesis 3 that stated Potential and Competencies Result have Simultaneously a Positive Influences on Performance Appraisal Echelon III Officials West Nusa Tenggara Province.

\subsection{Classic Assumption After Data Analysis}

After analyzing the data using simple regression methods and multiple linear regression, there are several more classic assumptions that must be met to test the validity of the resulting regression line equation. Some of the classic assumption tests include :

1. Heteroscedasticity test (Glejser) : This test is part of the classical assumption test in regression analysis which aims to test whether in the regression model there is an inequality of variance from the residual value of one observation to another is fixed, it is called homoscedasticity. Conversely, if the residual value of one observation to another is different, it is called heteroscedasticity. A good regression model should not indicate heteroscedasticity [45]. 


\section{Kresna Social Science and Humanities Research}

Proceedings of the International Conference On Ummah:

Digital Innovation, Humanities And Economy (ICU: DIHEc) 2020

https:/doi.org/10.30874/ksshr.6

Table 10.

Coefficients Heteroscedasticity Glejser Test

\begin{tabular}{|l|c|c|}
\hline \multicolumn{1}{|c|}{ Variables } & $\mathrm{t}$ & $\mathrm{P}$ \\
\hline Potential & -1.735 & 0.088 \\
\hline Competencies & -1.629 & 0.109 \\
\hline
\end{tabular}

The basis for decision making in the heteroskedacity test using the Glejser test is as follows [45]:

a. If the significant value $(\mathrm{P})$ is greater than 0.05 , the conclusion is that there is no indication of heteroskedacity in the regression model.

b. Conversely, if the significance value $(\mathrm{P})$ is smaller than 0.05 , then the conclusion is an indication of heteroskedacity in the regression model.

In the Glejser test results of this research data obtained the test results with a significance value $(\mathrm{P})$ greater than 0.05 , it can be concluded that the two independent variables (Potential and Competency) there are no indication of heteroskedacity.

2. Autocorrelation Test : A statistical analysis was carried out to find out whether there was a correlation between variables in the prediction model and the change in time. Therefore, if the assumption of autocorrelation occurs in a prediction model, then the value of disturbance is no longer freely paired, but paired by autocorrelation. Autocorrelation is actually a value in a particular sample or observation strongly influenced by the value of previous observations [45].

Table 11.

Autocorrelation Asumption Test Result

\begin{tabular}{|c|c|c|c|c|c|}
\hline Model & $\mathrm{R}$ & $\mathrm{R}^{2}$ & $\begin{array}{c}\text { Adjusted } \\
\mathrm{R}^{2}\end{array}$ & $\begin{array}{c}\text { S.tdr } \\
\text { Eror }\end{array}$ & $\begin{array}{c}\text { Durbin- } \\
\text { Watson }\end{array}$ \\
\hline 1 & 0.640 & 0.410 & 0.389 & 3.159 & 1.668 \\
\hline
\end{tabular}

OUTPUT SPSS 26

To detect autocorrelation can be seen in the Durbin-Watson table, in general we can take a benchmark [45] :

a. A Durbin-Watson number below -2 means there is a positive autocorrelation.

b. A Durbin-Watson number between -2 to +2 means there is no autocorrelation.

c. Durbin-Watson numbers above +2 mean there is a negative autocorrelation. 


\section{Kresna Social Science and Humanities Research}

Proceedings of the International Conference On Ummah:

Digital Innovation, Humanities And Economy (ICU: DIHEc) 2020 https:/doi.org/10.30874/ksshr.6

From the assumption test results above the Durbin-Watson value in this study was 1.668 , meaning that it was between the values of -2 and +2 . So it can be concluded that the variables in this study do not indicate Autocorrelation.

3. Outlier Assumptions Test : Understanding outliers is observational data that appears with extreme values, both univariate or multivariate. Extreme Value is a value that is far or completely different from most other values in the group. Univariate outliers are data caused by Dependent variables. If this is left unchecked, it can cause residual normality problems in linear regression. Furthermore, value R and R Squared will be biased, meaning that in linear regression value $\mathrm{R}$ Squared is incorrect in explaining dependent variables. Multivariate Outliers are data caused by a set of Independent variables. If one or several free variables have extreme values, then there is the possibility that multivariate outliers can occur [45].

Table 12.

Outlier Assumption Test Result

\begin{tabular}{|c|c|c|c|c|c|}
\hline $\begin{array}{c}\text { STd. } \\
\text { Predicted } \\
\text { Value }\end{array}$ & Minimum & Maximum & Mean & $\begin{array}{c}\text { Std. } \\
\text { Deviation }\end{array}$ & $\mathrm{N}$ \\
\hline Residual & -2.584 & 2.830 & 0.000 & 1.000 & 60 \\
\hline
\end{tabular}

OUTPUT SPSS 26

The results of the analysis show the residual number with a mean of 0,000 and a standard deviation of 1.00 , there were no outlier cases in this research variable.

\subsection{Discussion of The Result}

After analyzing the two Independent variables (Potential and Competence) included in the regression model. The coefficient of determination ( $\mathrm{R}$ Squared) shows the value of 0.410 meaning that the regression model obtained can explain $41 \%$ of the variation in the performance variable of echelon III officials of the NTB provincial government. Then the F test results that indicate the value of $\mathrm{P}($ sign $)=$ 0.0001 , means that at $5 \%$ alpha we can state that the regression model matches the available data. From the coefficient results obtained by the regression equation as follows:

\section{Performance Appraisal $=44.303+0.331$ Potential +0.764 Competencies}

From the equations above can predict the performance of echelon III officials of NTB province. Then 


\section{Kresna Social Science and Humanities Research}

Proceedings of the International Conference On Ummah:

Digital Innovation, Humanities And Economy (ICU: DIHEc) 2020

https:/doi.org/10.30874/ksshr.6

based on the value of the coefficient B of each variable can be interpreted as follows:

a. Constant $B=44,303$ means that if the potential and competency value is 0 , the performance appraisal is 44,303

b. Constant $\mathrm{B} 1=0.331$ means that if the potential value is increased by 1 unit, the performance appraisal will increase by 0.331 .

c. Constant B2 $=0.764$ means that if the competency is increased in value by 1 unit, the performance appraisal will increase by 0.764 .

Based on the regression equation above, an example of the calculation of echelon III official performance is as follows :

For example, an echelon III official has a potential value of 70 and competence of 60 , then the equation

Performance Appraisal :

$$
\begin{aligned}
& =44.303+0.331(70)+0.764(60) \\
& =44.303+23.17+45.84 \\
& =113.313
\end{aligned}
$$

Based on the performance score obtained from the above calculation $(113,313)$, it can be concluded that the performance of echelon III officials is very good because it is between 110 to 120 .

Table 13.

Dominance Factor From The Variables (Independent)

\begin{tabular}{|l|c|c|}
\hline \multicolumn{1}{|c|}{ Variable } & Beta & P Value \\
\hline Potential & 0.383 & 0.000 \\
\hline Competency & 0.523 & 0.000 \\
\hline
\end{tabular}

OUTPUT SPSS 26

The two Independent variables (potential and competency) were found to be significant ( $\mathrm{P}$ value $<0.05$ ), of the two variables the greatest influence on performance appraisal was competency $($ Beta $=0.523)$.

\section{Conclusions}

From the results of the analysis and description of the previous chapter conclusions can be drawn as follows:

a. For the first hypothesis, based on a simple regression analysis, it was found that $\mathrm{P}<0.004$ which means that the results are significant. Therefore, the first hypothesis that reads "Potential Employee Has a Positive Impact on Performance Appraisal" can be accepted. Independent Variable (potential) $\mathrm{R}$ Squared determination coefficient $=13.7 \%$, this means that the potential 


\section{Kresna Social Science and Humanities Research}

Proceedings of the International Conference On Ummah:

Digital Innovation, Humanities And Economy (ICU: DIHEc) 2020 https:/doi.org/10.30874/ksshr.6

variable in the hypothesis has a contribution of $13.7 \%$ to the dependent variable performance appraisal. The remaining $86.3 \%$ is influenced by variables outside the model.

b. For the Second hypothesis, based on a simple regression analysis, it was found that $\mathrm{P}<0.001$ which means that the results are significant. Accordingly, the second hypothesis that refers to "Competencies Employee Has a Positive Impact on Performance Appraisal" can be accepted. Independent Variable (competencies) R Squared determination coefficient $=26.3 \%$, this means that the competencies variable in the hypothesis has a contribution of $26.3 \%$ to the dependent variable performance appraisal. The remaining $73.7 \%$ is effect by variables outside the model.

c. For the third hypothesis, based on multiple linear regression analysis, it was found that $\mathrm{P}<0.001$, which means that the results are significant. Therefore, the third hypothesis which reads "Potential and Competencies of Employees Has a Positive Impact on Performance Appraisal" can be proven. Both of Independent Variables have simultaneously influence toward dependent variable. Independent Variables (Potential and competence) R squares determination coefficient $=41 \%$, this means that the potential and competency variables simultaneously have to contribute $41 \%$ to the performance appraisal of the dependent variable. The remaining $59 \%$ is generated by variables outside the model.

d. The performance of echelon III officials of NTB province is at a fairly good level.

e. The echelon III officials of NTB province are on average 50 years old, and there are more male officials than women. The officials have an average potential score of 41,466 and 36,116 for competencies score.

f. From the two independent variables (Potential and competence) that had the greatest influence on the dependent variable (Performance Appraisal), the Echelon III Officer of NTB Province was competency $($ Beta $=0.523)$. 


\section{Kresna Social Science and Humanities Research}

Proceedings of the International Conference On Ummah:

Digital Innovation, Humanities And Economy (ICU: DIHEc) 2020

https:/doi.org/10.30874/ksshr.6

\section{References}

[1] M. Armstrong, "Performance management: Key strategies and practical guidelines," 2006.

[2] A. D. Timpe, Seri Manajemen Sumber Daya Manusia : kinerja, 6/ Timpe.

[3] R. Veithzal and A. F. M. Basri, "Performance Appraisal," Jakarta. PT Raja Grafindo Persada, 2005.

[4] D. C. McClelland and R. E. Boyatzis, "Opportunities for counselors from the competency assessment movement," The Personnel and Guidance Journal, vol. 58, no. 5, pp. 368-372, 1980.

[5] O. Iversen, "MANAGING PEOPLE TOWARDS A MULTICULTURAL WORKFORCE: AN INVESTIGATION INTO THE IMPORTANCE OF MANAGERIAL COMPETENCIES ACROSS NATIONAL BOARDERS IN EUROPE-DIFFERENCES AND SIMILARITIES," 2000: WORLD CONGRESS ON HUMAN RESOURCE MANAGEMENT.

[6] L. M. Spencer and P. S. M. Spencer, Competence at Work models for superior performance. John Wiley \& Sons, 2008.

[7] S. Gupta, "Competency-A Prospect or Retrospect," Available at SSRN 645241, 2005.

[8] D. C. McClelland, "Testing for competence rather than for" intelligence."," American psychologist, vol. 28, no. 1, p. 1, 1973.

[9] D. Ruth, "Frameworks of managerial competence: limits, problems and suggestions," Journal of European Industrial Training, vol. 30, no. 3, pp. 206-226, 2006.

[10] A. R. Levenson, W. A. Van der Stede, and S. G. Cohen, "Measuring the relationship between managerial competencies and performance," Journal of Management, vol. 32, no. 3, pp. 360380, 2006.

[11] F. Patterson, E. Ferguson, P. Lane, K. Farrell, J. Martlew, and A. Wells, "A competency model for general practice: implications for selection, training, and development," Br J Gen Pract, vol. 50, no. 452, pp. 188-193, 2000.

[12] F. Draganidis and G. Mentzas, "Competency based management: a review of systems and approaches," Information management \& computer security, vol. 14, no. 1, pp. 51-64, 2006.

[13] N. Megahed, "A Critical Review of the Literature and Practice of Competency Modelling," KnE Social Sciences, pp. 104-126-104-126, 2018.

[14] T. Jurnali and A. Siti-Nabiha, "Performance management system for local government: The Indonesian experience," Global Business Review, vol. 16, no. 3, pp. 351-363, 2015.

[15] I. K. Dewi, S. Sampara, H. Baharuddin, and M. S. Nuh, "The Nature Public Service In Making A Good Governance."

[16] S. Tyson, Essentials of human resource management. Routledge, 2014.

[17] N. Binder, "Performance and talent: Introduction and overview," Handbook of Human Resource Management, pp. 407-26, 2016.

[18] M. Zeuch, Handbook of Human Resources Management. Springer, 2016.

[19] R. E. Boyatzis, "Competencies as a behavioral approach to emotional intelligence," Journal of Management Development, vol. 28, no. 9, pp. 749-770, 2009.

[20] M. Armstrong, Armstrong's essential human resource management practice: A guide to people management. Kogan Page Publishers, 2010.

[21] D. T. Hall and J. E. Moss, "The new protean career contract: Helping organizations and employees adapt," Organizational dynamics, vol. 26, no. 3, pp. 22-37, 1998.

[22] M. Armstrong, Armstrong's handbook of strategic human resource management. Kogan Page Publishers, 2011.

[23] M. Armstrong and S. Taylor, Armstrong's handbook of human resource management practice. Kogan Page Publishers, 2020.

[24] S. Ed, "Career Anchors," ed: Jossey-Bass, San Francisco, 1993.

[25] A. J. Elliot, C. S. Dweck, and D. S. Yeager, Handbook of competence and motivation: Theory and application. Guilford Publications, 2017. 


\section{Kresna Social Science and Humanities Research}

Proceedings of the International Conference On Ummah:

Digital Innovation, Humanities And Economy (ICU: DIHEc) 2020

https:/doi.org/10.30874/ksshr.6

[26] R. Edenborough, Assessment methods in recruitment, selection \& performance: a manager's guide to psychometric testing, interviews and assessment centres. Kogan Page Publishers, 2007.

[27] R. Boyatzis, "Competencies in the 21 st century," Journal of Management Development, vol. 27, 01/04 2008, doi: 10.1108/02621710810840730.

[28] J. C. Flanagan, "The critical incident technique," Psychological bulletin, vol. 51, no. 4, p. 327, 1954.

[29] C. A. Dailey, Assessment of lives: Personality evaluation in a bureaucratic society. John Wiley \& Sons, Incorporated, 1971.

[30] R. E. Boyatzis, The competent manager: A model for effective performance. John Wiley \& Sons, 1982.

[31] D. W. Bray, R. J. Campbell, and D. L. Grant, Formative years in business: A long-term AT\&T study of managerial lives. Wiley-Interscience, 1974.

[32] A. Howard and D. W. Bray, Managerial lives in transition: Advancing age and changing times. Guilford Press, 1988.

[33] J. P. Kotter, "What effective general managers really do," Harvard business review, vol. 60, no. 6, pp. 156-167, 1982.

[34] F. Luthans, R. M. Hodgetts, and S. A. Rosenkrantz, Real managers. Ballinger, 1988.

[35] G. Thorton, "et Byham, W.(1982). Assessment Centers and Managerial Performance. Florida," ed: Academic Press inc.

[36] J. J. Campbell, M. D. Dunnette, E. E. Lawler, and K. E. Weick, "Managerial behavior, performance, and effectiveness," 1970.

[37] D. Goleman, "Working with emotional intelligence. Bantam," New York, 1998.

[38] L. Spencer Jr and S. Spencer, "Competence at Work: Models for Superior Performance. John Wiley \& Sons. Nueva York," 1993.

[39] A. Wilkinson, T. Redman, and T. Dundon, Contemporary human resource management: text and cases. Pearson London, 2017.

[40] R. E. Boyatzis and F. Sala, "Assessing emotional intelligence competencies," The measurement of emotional intelligence, pp. 147-180, 2004.

[41] D. C. McClelland, Human motivation. CUP Archive, 1987.

[42] R. Boyatzis and R. E. Boyatzis, "An overview of intentional change from a complexity perspective," Journal of management development, 2006.

[43] M. Easterby-Smith, R. Thorpe, and P. R. Jackson, Management research. Sage, 2012.

[44] A. Bryman and E. Bell, "Business Research Methods (Vol. fourth)," Glasgow: Bell \& Bain Ltd, 2015.

[45] S. Brandt and S. Brandt, Data analysis. Springer, 1999. 